\title{
ASSESSMENT OF TRADITIONAL ARCHITECTURE OF LUCKNOW WITH REFERENCE TO CLIMATIC RESPONSIVENESS
}

\author{
Mohammad Arif Kamal \\ Architecture Section, Aligarh Muslim University \\ Aligarh, India
}

E-mail: architectarif@gmail.com

\begin{abstract}
Introduction: Traditional architecture, all over the world, has many characteristics that ensure thermal comfort. In the past, people built their houses in harmony with the environment, while also optimally utilizing the building materials available locally. The traditional built form was climate-responsive; it evolved over centuries of experience and observations of climate and nature. The traditional local architecture of Lucknow (a North Indian historical city) has employed some ingenious natural and passive techniques to maintain thermal comfort within the building, particularly during the hottest hours of the day. In this paper, we discuss the traditional built form of Lucknow through the lens of its climatic appropriateness, especially during the hottest hours of the day. Methods: The research methodology involves the study of the thermal performance of two traditional houses and one modern dwelling unit in Lucknow during the climatic extremes, i.e. summer and winter, by means of on-site monitoring of temperature and relative humidity. Results and discussion: We have summarized the comparative analysis of the thermal performance of traditional houses and modern houses and drawn conclusions from the factors that are responsible for providing thermal comfort. The analysis shows that the use of natural and passive techniques in the traditional buildings of Lucknow is very effective in terms of providing a thermally comfortable space, warm in the winter and cool in the summer.
\end{abstract}

\section{Keywords}

Traditional architecture, climatic design, climate responsiveness, Lucknow, India.

\section{Introduction}

The construction sector is one of the main contributors to energy dependence and consumption. The depletion of energy resources and the risk of global warming are creating a need for sustainable development in the construction sector, based on renewable energy and energy efficiency (Robert and Kummert, 2012). The dependence of architecture on energy for achieving a habitable space that is comfortable during all seasons and external climatic conditions is a highly non-viable proposition. The promotion and propagation of energy-dependent architecture is a significant lacuna on the architects' part. The architects have not incorporated the insights of the bioclimatic design principles and have merely left all lighting and ventilation to the mechanical and energy-consuming devices (Coch, 1998). At a time when humanity is facing the worst effects of climate change, energy crisis, and rapid urbanization, it is logical to look for ecologically sustainable design (Bay, 2010). The building should respond to the climate of the region where it is situated. All architectural design should respond to the environment and harness its beneficial aspects. This response can be achieved through layout design, orientation, and the scale of the building, all of which should be relevant to the context (Krishan et al., 2001).

Bioclimatic architecture integrates the microclimate and architecture for achieving thermal conditions that are comfortable to humans (Sayigh and Marafia, 1998). Bioclimatic concepts were widely implemented in the architecture of the early times, before the mass introduction of mechanical devices for altering the indoor comfort conditions. An in-depth understanding of traditional architecture gives us clues on sustainable design that offers a responsible approach to climate, energy consumption, and preserving the environment (Asquith and Vellinga, 2006). History has shown us that architectural built forms have evolved in response to the climate, lifestyle, and availability of building materials. Although housing typologies are the result of multiple determinants, climate and culture are the two most important determinants (Rapoport, 1969).

\section{Climatic Design and Traditional Architecture}

By understanding traditional architecture in terms of heat, humidity, air movement, light, and in relation to the physical environment, we learn vital lessons for the present design endeavours. In many traditional buildings, both primitive and vernacular, some ingenious solutions to the architectural problems of resisting extremes of weather and maintaining a comfortable indoor climate can be seen (Sangkertadi et al., 2008). The traditional buildings of the past provide the best pointers in this regard; we have outstanding evidence of them being climate-responsive and energy-conscious. The basic form of the traditional building employs 
a combination of mass, shade, and ventilation, which lets the building breathe in harmony with nature and ensures the comfort of the occupants inside. In traditional architecture, an effort is made toward utilizing natural resources as much as possible. The ancient structures were designed in such a way that there was no need for $A C$, coolers, or fans for creating a thermally comfortable environment. They had inbuilt features for providing thermal comfort. The familiar elements of regional architectural styles, i.e. verandas, balconies, projections, courtyards, air shafts, thick walls, high ceilings, ventilation apertures, etc. were designed to use the sun for warmth and light and to create shade and breeze for cooling. We can learn these climatic design lessons and seek inspiration by observing the long history of traditional architecture (Vissilia, 2009). The natural and passive systems in buildings use non-mechanical methods to maintain a comfortable indoor temperature and are a key factor in mitigating the impact of buildings on the environment. Their designs are based on years of experience, building upon the relationship between the structure and climate and implying a logical analysis, the consideration of appropriate principles, and the rational use of resources (Kamal, 2007).
Traditional architecture in India is vibrant in terms of variety, which can be witnessed across the length and breadth of the country. The concepts of space planning are well adapted to people's needs and the climate. Continuity of tradition needs planning, design regulations and guidelines as well as the establishment of a code of practice to govern and control the proper implications of immutables, regardless of whether the technology is new or traditional (Saleh, 1999). The traditional houses of Lucknow are climatically responsive buildings that have evolved over centuries of experience and observations of climate and nature. The traditional residential buildings in Lucknow have employed some ingenious natural and passive features and techniques to maintain thermal comfort inside. Despite the long, hot summer with the dry-bulb temperature of up to $45^{\circ} \mathrm{C}$, humans feel comfortable inside these traditional buildings thanks to the utilization of natural and passive cooling techniques. The research in this paper involves the study of the thermal performance of two traditional houses and one modern dwelling unit in Lucknow during the climatic extremes, i.e. summer and winter, by means of on-site monitoring of temperature and relative humidity.

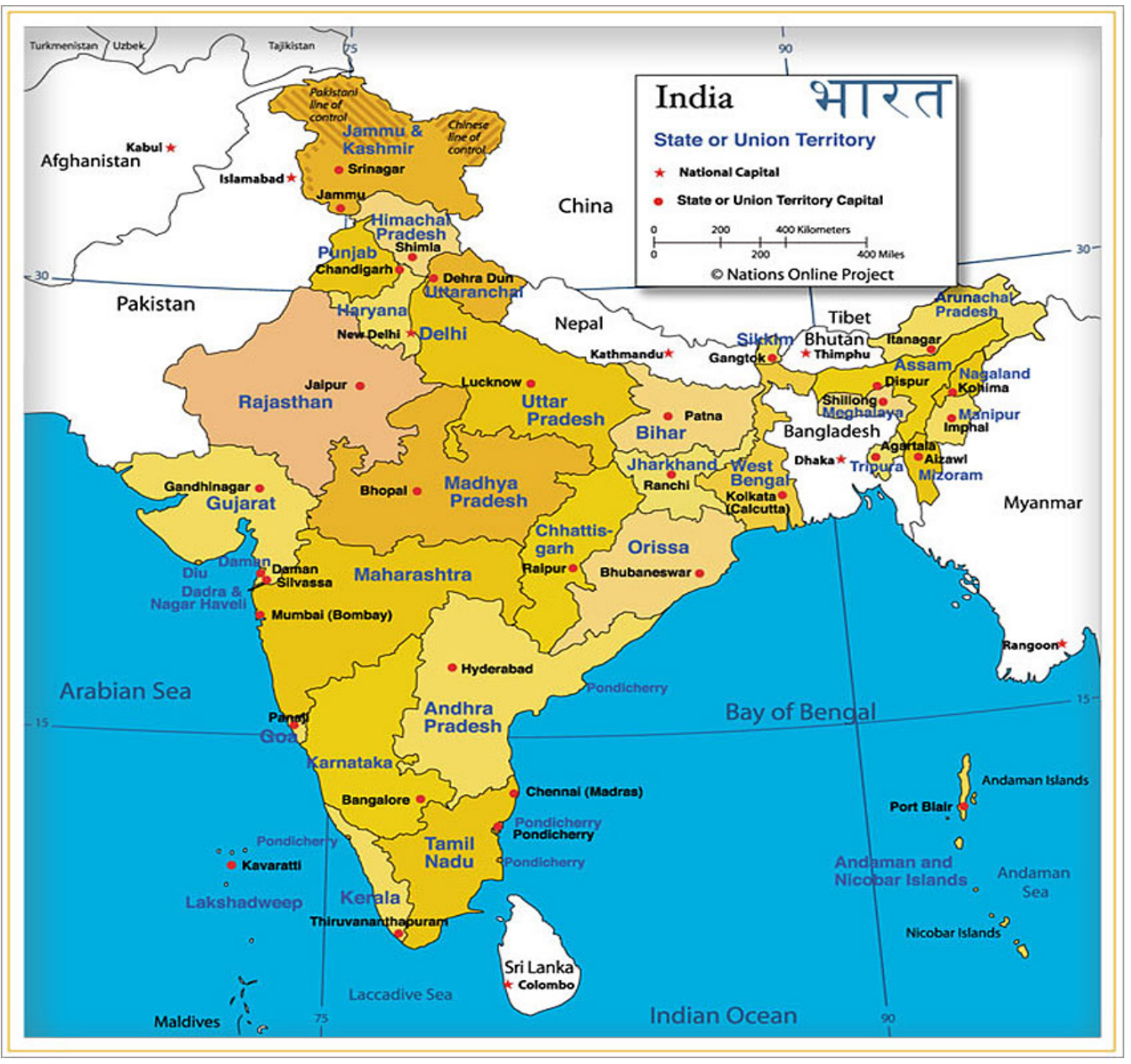

Figure 1. Map of India showing the location of Lucknow (Source: https://www.nationsonline.org/bilder/map_of_india50.jpg) 


\section{Research Methodology}

The research hypothesis is that the traditionally constructed and designed houses are more climate-responsive than the houses with modern constructional designs. Our research methodology involved the identification of various natural and passive design features employed in the traditional residential buildings in the old settlement of Lucknow. The research also involved the study of thermal performance through on-site monitoring of two traditional houses and one modern dwelling unit in Lucknow. We used both quantitative and qualitative methods of gathering data. These included:

1. Documenting the building's physical form and construction systems.

2. Recording the thermal performance parameters in all three buildings during the period of climatic extremes. Our experiments were conducted during the third week of January 2004 and the first week of June 2004. The temperature and relative humidity were measured with a digital thermo-hygrometer outside each building, as

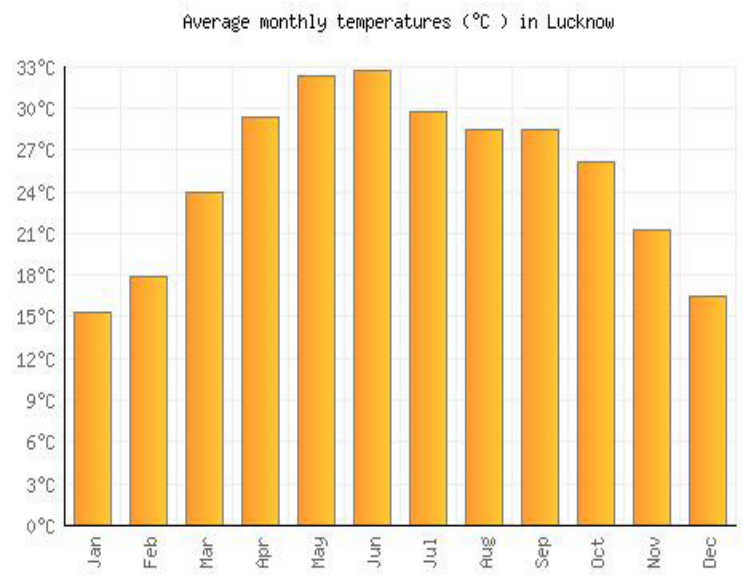

Figure 2. Average monthly temperatures $\left({ }^{\circ} \mathrm{C}\right)$ in Lucknow (Source: https://www.weather2visit.com/asia/india/lucknow.htm)

Relative humidity in Lucknow

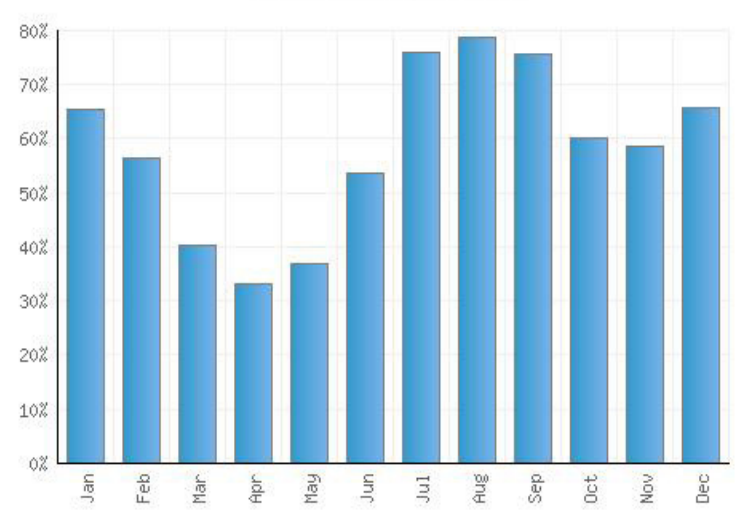

Figure 3. Relative humidity percentage in Lucknow (Source: https://www.weather2visit.com/asia/india/lucknow.htm) well as in different indoor spaces, every two hours over the course of a complete one-day cycle.

3. Comparing the buildings' thermal performance.

\section{Lucknow: The Study Context}

The city of Lucknow is situated in the plains of Northern India, on the banks of the Gomti River. It is the capital of Uttar Pradesh, the most populous state of India (Fig. 1). The city is famous for its rich Nawabi culture and traditions and its intricately carved buildings. The Nawabs (rulers) of Lucknow not only built fine structures in traditional styles and experimented with European architecture, but also created a novel hybrid style, which was an amalgamation of both Indian and European elements (Tandan, 2001). The city has the older habitations in the central part and the newer settlements all around it. The older buildings are located in the centre of the city, surrounded by newer settlements. The older areas of the city (south of the Gomti River) are characterized by high density and pre-colonial settlement structures. The outer and peripheral

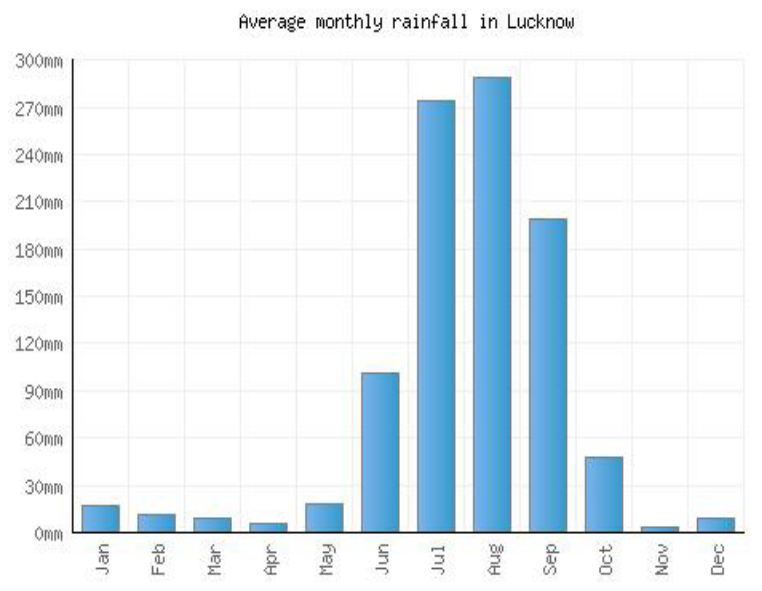

Figure 4. Average monthly rainfall data for Lucknow (Source:https://www.weather2visit.com/asia/india/lucknow.htm)

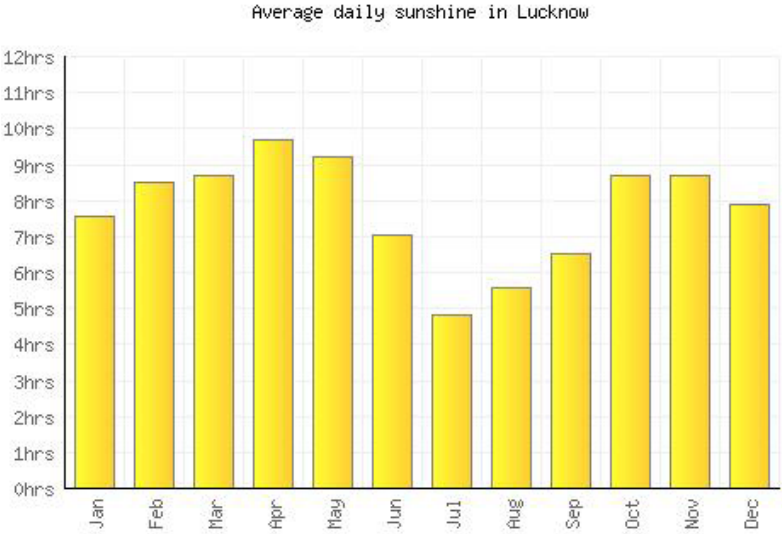

Figure 5. Average daily sunshine hours per month in Lucknow (Source: https://www.weather2visit.com/asia/india/lucknow.htm) 


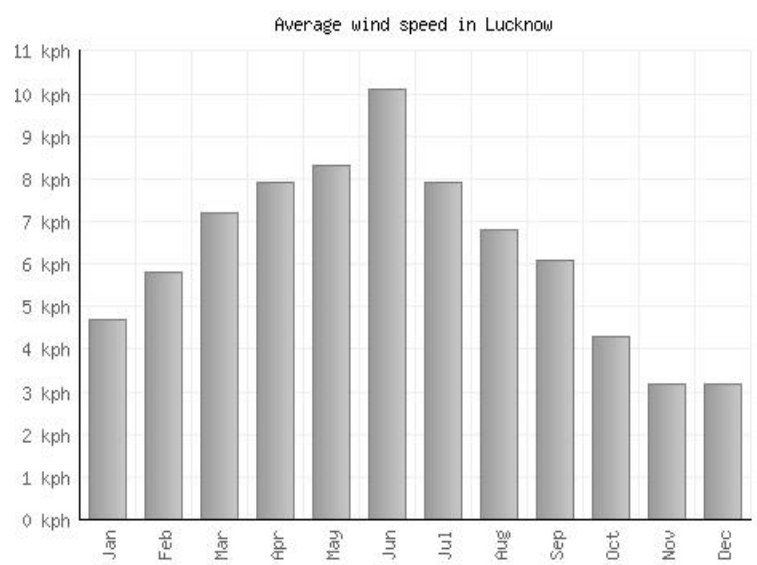

Figure 6. Average wind speed data in $\mathrm{km} / \mathrm{hour}$ in Lucknow (Source:https://www.weather2visit.com/asia/india/lucknow.htm)

areas have primarily been settled in the postindependence period.

\section{Climatic Data for Lucknow}

Lucknow lies within a composite climate zone, having four main seasons: the summer, which is hot and fairly dry; the monsoon, which is less hot but humid; the period of moderate temperatures and humidity; and the slightly cold winter period. The climatic data for the last twenty years, published by the Central Building Research Institute, Roorkee, is summarized below (CBRI, 1989):

\section{Air Temperature}

The average monthly maximum temperature during the year's hottest month (May) is $41.2^{\circ} \mathrm{C}$, while the average monthly minimum temperature during the year's coldest month (Jan) is $8.9^{\circ} \mathrm{C}$ (Fig. 2).

\section{Relative Humidity}

The relative humidity during the summer can be less than $25 \%$; during the most humid months, the relative humidity is in the range of $78 \%$ to $82 \%$, whereas the air temperature is in the range of $32.5^{\circ} \mathrm{C}$ to $34^{\circ} \mathrm{C}$ (Fig. 3).

\section{Rainfall}

Rainfall starts with the arrival of the monsoon season in the middle of June. Regular rains continue up to mid-September. The total annual rainfall is 940 mm (Fig. 4).

\section{Solar Radiation and Sunshine}

The sky is mostly clear throughout the year. The average solar radiation on a horizontal surface in June is $20.2 \mathrm{MJ} / \mathrm{m}^{2}$ per day. Lucknow experiences 8 to 10 hours of sunshine for nine months (from October to June) and 5 to 6 hours during the remaining three months (Fig. 5). The sky remains normally overcast during the rainy season.

\section{Wind Speed}

The wind speed is in the range of 8 to $10 \mathrm{~km} /$ hour from May to September (Fig. 6). The predominant wind direction is east.

\section{Traditional Architecture of Lucknow}

The traditional architecture of Lucknow has evolved through the entire spectrum from individual buildings to settlement patterns; it responds to climate through form, thermal mass, spatial hierarchy, activity pattern, material, and construction.

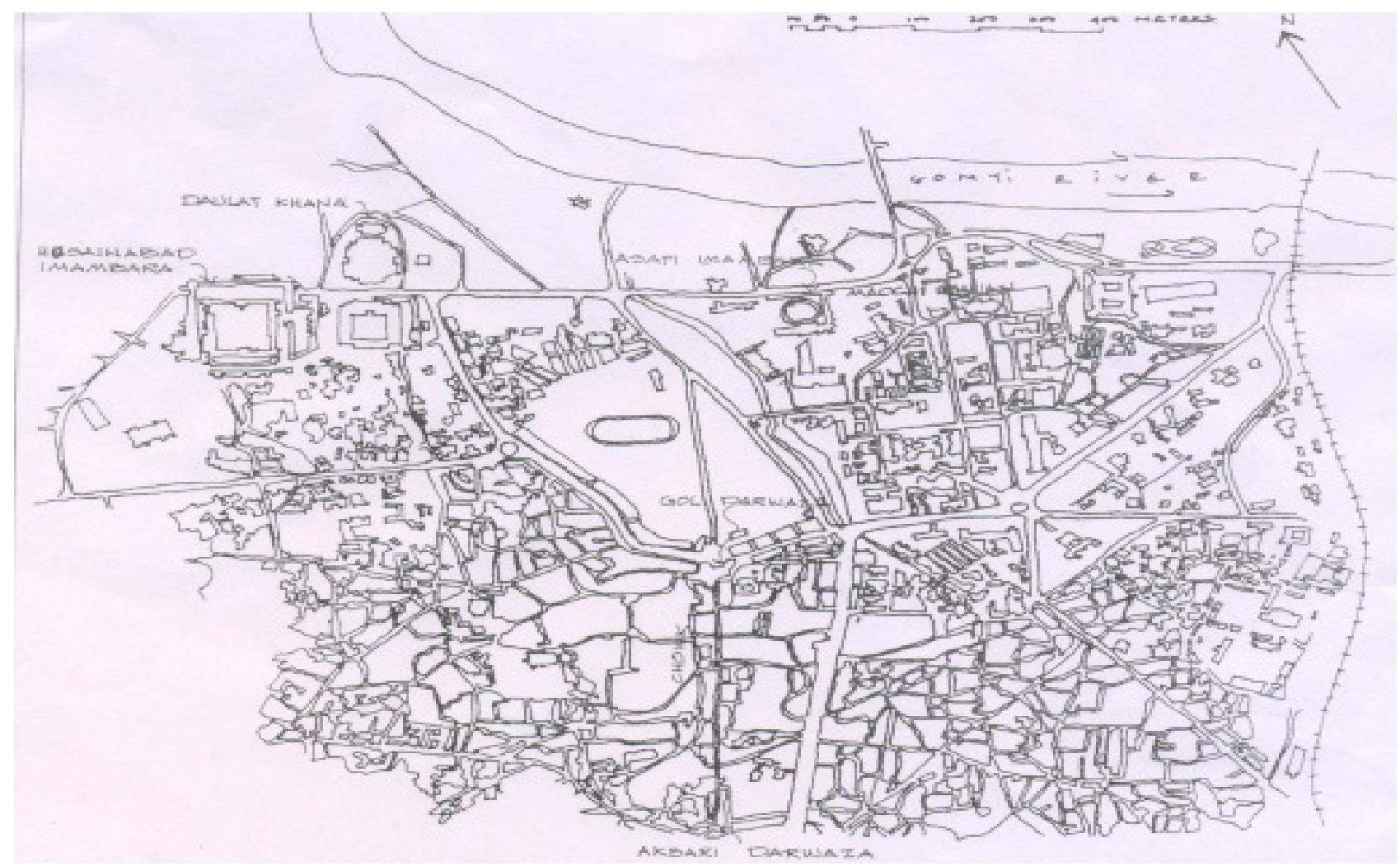

Figure 7. Dense settlement plan of Lucknow (Source: the author of the paper) 


\section{City Layout and Street Pattern}

The city has two discernible entities: older buildings in the centre of the city and the surrounding newer settlements. The older areas of the city (largely south of the Gomti River) are characterized by high density and pre-colonial settlement structures (Fig. 7). The older urban settlement was compact and mostly planned around courtyards, which addressed the climate and the need for social interactions. The outer and peripheral areas have been settled in the post-independence period. The urban fabric is so tightly knit in the old city that the streets feel like elongated courtyards carved out through the dense building mass (Sinha and Kant, 2000). The streets in the older settlements are narrow and winding. The width of the streets varies from 3 to $5 \mathrm{~m}$. As the streets meander slightly, there are no views down their entire length. The streets act as linkages and activity and interaction spaces. The height of the buildings is greater than the width of the streets, sufficiently so to create a shaded environment where the pedestrians can walk and share social activities in the streets.

\section{House Form}

Lucknow has its own traditions and culture, largely influenced by the religion and beliefs of its people. The traditional houses of Lucknow were built with three main considerations: privacy, segregation between men and women, and response to the hot climate. These factors have a great influence on the design of the houses that people still live in. There are two types of traditional residential buildings, depending on the socio-economic status of their inhabitants. The first type of traditional houses includes kothis, havelis, and palaces, which were commissioned by the Nawabs and their courtiers. These were the examples of outstanding Nawabi domestic architecture. Houses of the second type belong to middle-income people. The house plan and design are characterized by the presence of a courtyard, and sometimes an underground level as well. The houses open into the narrow streets through a hierarchy of spaces, such as the veranda,
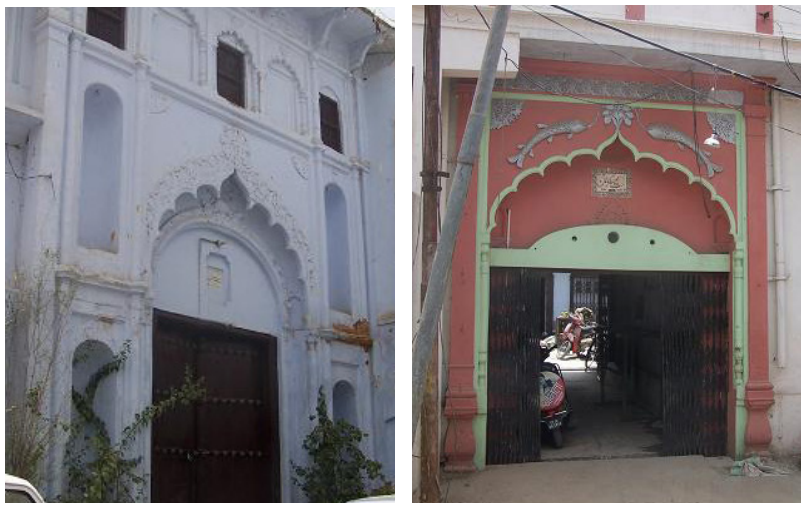

Figure 8. Articulated street facade of traditional Lucknow houses (Source: the author of the paper) the entrance lobby, etc., which form a buffer zone between the street and the house (Fig. 8). The buildings are $2-3$ storeys in height, frequently with a balcony on the first or second floor. This house type can be considered the generic traditional Lucknow house. It has a simple layout, with a veranda and a courtyard surrounded by rooms on all sides. The upper storey comprises one or two rooms with terraces, balconies, and pavilions.

\section{Building Construction and Materials}

The most common building materials used in the traditional houses of Lucknow are lakhauri bricks and lime. The thick masonry walls are constructed with lakhauri bricks and mortar, made out of lime and surkhi. The thickness of masonry walls generally varies from 45 to $90 \mathrm{~cm}$ (Fig. 9). The walls are sometimes rough or mostly finished with lime and stucco plaster. The elevation of a typical traditional house is decorated with stucco, featuring motifs and floral patterns made out of lime plaster. The dressing of doors and windows is done with standard sets of mouldings made out of lime mortar. The roofs and floors use two types of construction. One method involves laying closely positioned timber beams and covering them with reed or grass matting, with a thick layer $(30-45 \mathrm{~cm})$ of lime concrete on top (Fig. 10). The second type of roof construction is a jack arch vaulted ceiling, made out of bricks on steel girders covered in thick lime concrete with brick ballasts. In both cases, the roofs and floor are finished with lime and cement plaster.

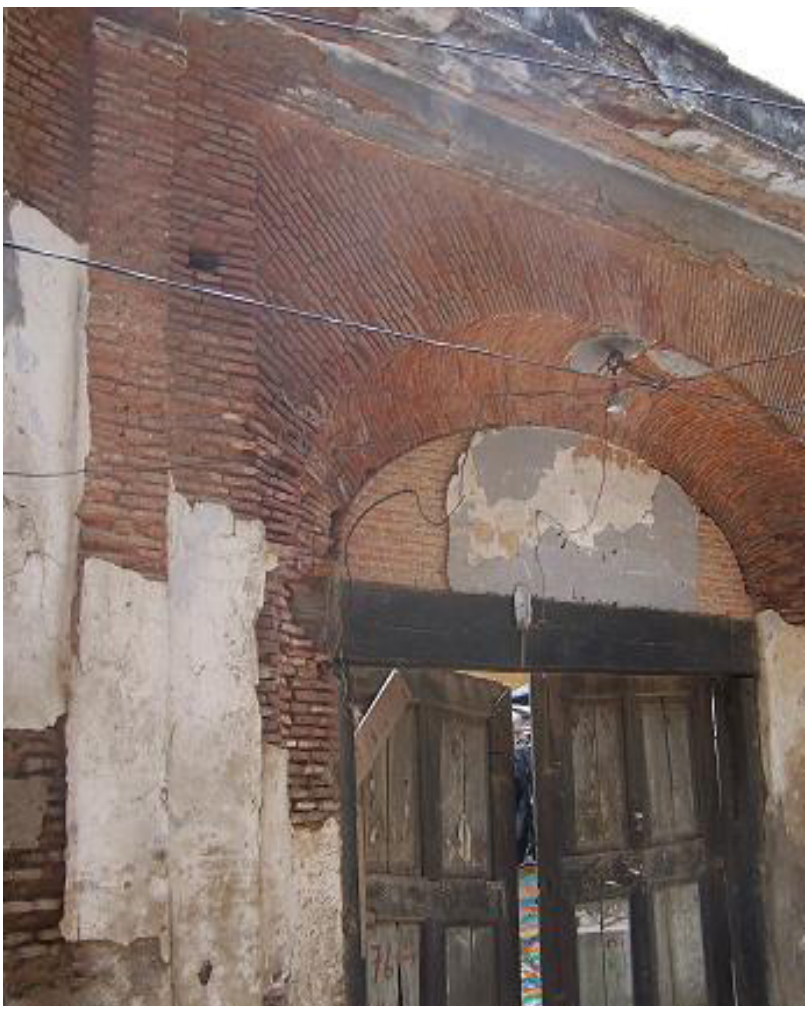

Figure 9. Thick masonry of lakhauri bricks in traditional houses (Source: the author of the paper) 


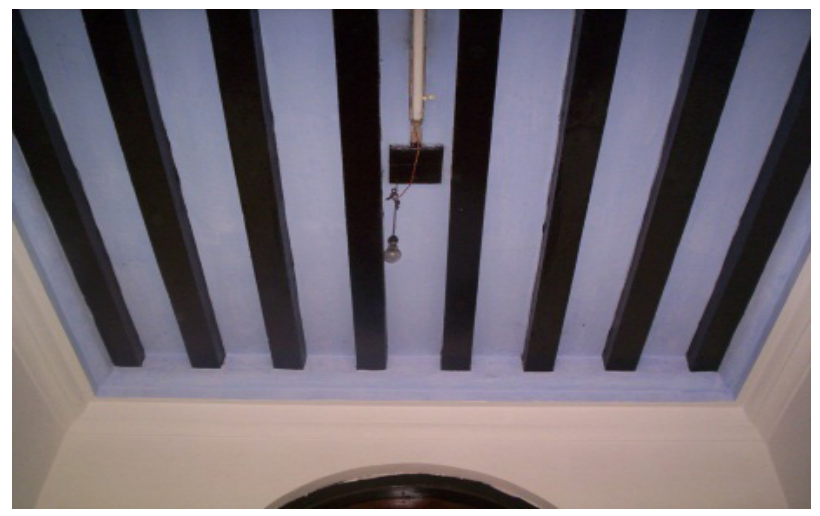

Figure 10. Heavy timber roof of traditional houses (Source: the author of the paper)

\section{Experimentation and Setting of the Investigation}

Rather than take detailed measurements of one building, we decided that it would be more efficient to take limited measurements in all three buildings, with the specific purpose of obtaining an overall view of the outdoor thermal environment instead of the variable micro-climate around the building. We must note that in the composite climate of Lucknow, the relative humidity has the most impact during the summer and the monsoon season, while being negligible in winter. Hence, the relative humidity was only measured during the summer months in all three houses. The main outdoor climatic parameters (air temperature and solar radiation) vary considerably throughout the year. The outdoor climatic data for Lucknow during the experiment period were obtained from the Indian Meteorological Department, which is not located in Lucknow. We found two stable zones, in June and December-January, which are also the periods for climatic extremes and therefore the obvious choice of a time frame for temperature observations. The tools available for measuring indoor parameters in this study were rather limited. Air temperatures and the relative humidity were measured with a digital thermo-hygrometer. The air

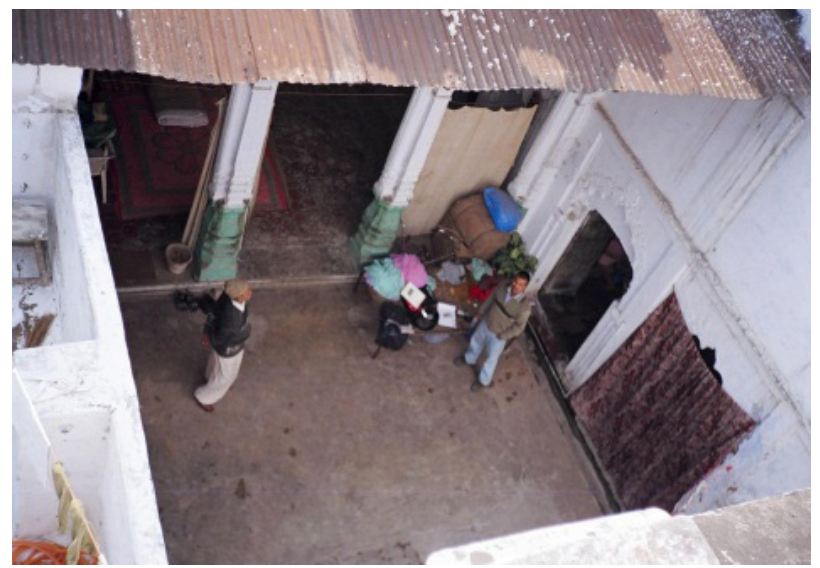

Figure 12. View of the central courtyard of Rizvi House (Source: the author of the paper)

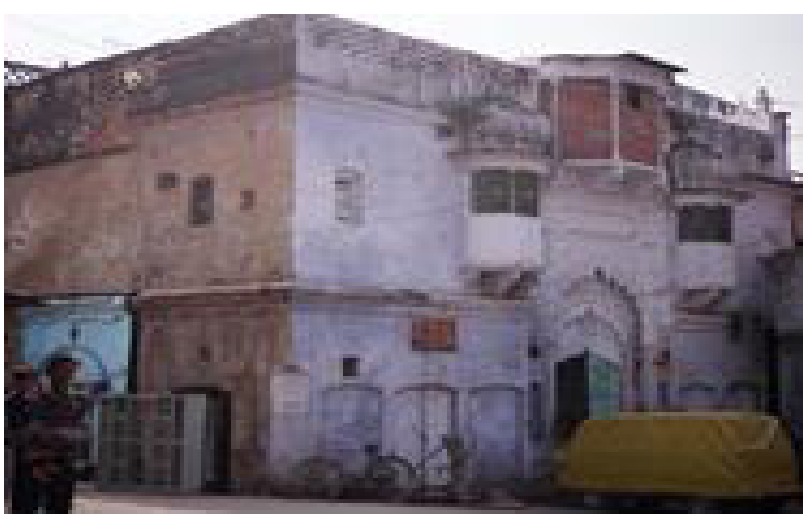

Figure 11. Exterior view of Rizvi House (Source: the author of the paper)

velocity was measured at windows with a portable digital wind vane, which provides an index of the relative airflow through a room at different times of the day, but does not detect the actual air velocity in the room at any given time (Kamal, 2007).

Thermal Performance of Traditional Architecture of Lucknow

\section{Case Study 1: Rizvi House}

This is a traditional courtyard house in Chowk, Lucknow, built around 1915 and meant to serve as a «Janana Imambara», or ladies' mourning place (Fig. 11). The mourning still takes place at the time of Moharram (first month of the Islamic calendar) in the Majisi, or the mourning hall; for the rest of the year, the Majlisi is used as a living room. Rizvi House is a two-storey building with a small central courtyard, 7.05 $x 6.4 \mathrm{~m}$. The courtyard is surrounded by living spaces on three sides and has an entrance on the north side (Fig. 12). The Majlisi is a two-level hall, which opens into three Imambaras in the front, two mosques on the right (at both levels), and a room on the left.

\section{Passive Features of Rizvi House}

The layout of the house is slightly shifted towards the west, maintaining the NE-SW orientation. The largest openings and the entrance are on the NE side, i.e. in the windward direction. There are few openings on the southeast side and no openings on the southwest side. The absence of openings on the exterior surfaces helps reduce heat. The main entrance opens into the narrow shaded street, meaning that cool air flows from the street into the building. The courtyard creates shaded spaces and facilitates ventilation in the interiors through the openings facing the courtyard. The eaves project into the courtyard, which provides shade and keeps direct solar radiation from entering the rooms that open into the courtyard (Fig. 13). The jharokhas on the northern face of the building catch prevailing wind, thus maintaining air circulation in the rooms on the first floor. The walls on the ground floor are $90 \mathrm{~cm}$ thick; on the first floor, the wall thickness decreases to $60 \mathrm{~cm}$. The masonry walls are constructed out of lakhauri bricks and finished with lime plaster (Fig. 
14). The roof is $36 \mathrm{~cm}$ thick; its structure includes a jack arch with lakhauri bricks on steel girders, finished with lime concrete. The massive walls and heavy roofs offer greater thermal resistance and hence increase the thermal time lag. The exterior and interior of the building are whitewashed, which helps reflect solar radiation.

Thermal Performance of Rizvi House in the

\section{Summer}

Figure 15 shows the thermal performance of different spaces inside and outside the building in the summer. The temperature in the room on the north side was found to be more stable as compared to other rooms. The outdoor temperature fluctuation was in the range of $17-18^{\circ} \mathrm{C}$, whereas the indoor temperature fluctuation was around $5-6^{\circ} \mathrm{C}$. The maximum indoor temperature was $8-9^{\circ} \mathrm{C}$ lower

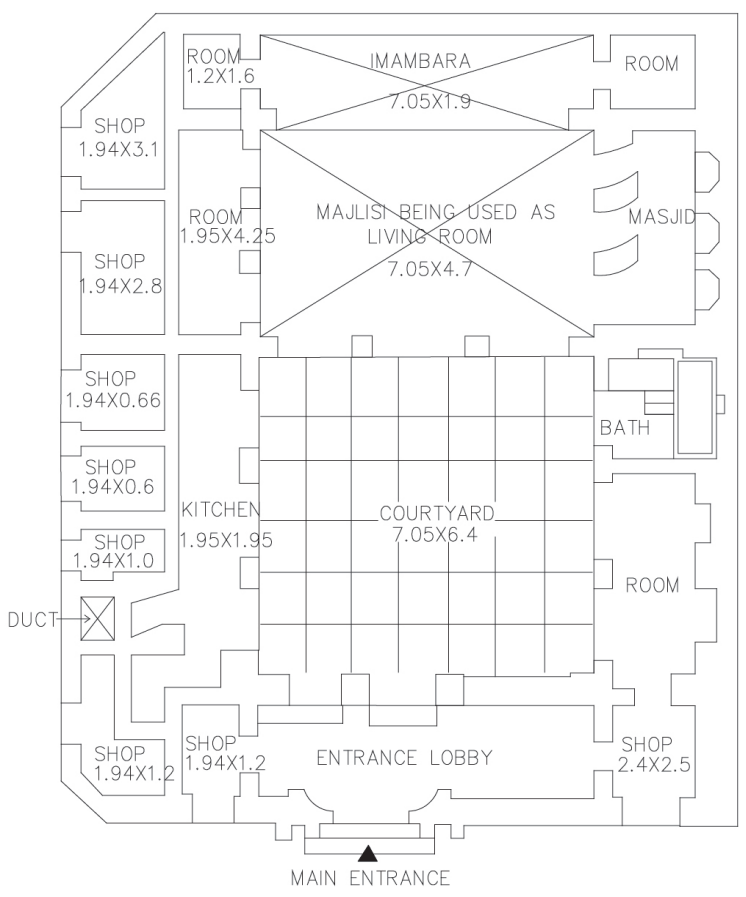

Figure 13. Ground-floor plan of Rizvi House

(Source: the author of the paper)

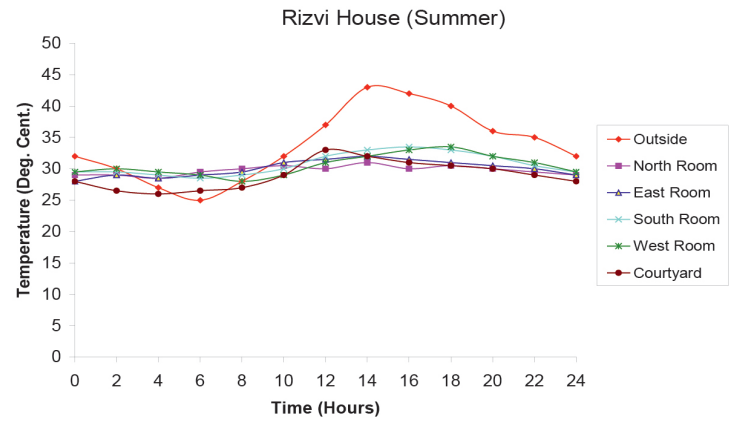

Figure 15. Summer temperature in different spaces in Rizvi House (Source: the author of the paper) than the corresponding outdoor temperature. While the outdoor air temperatures changed from 25 to $43^{\circ} \mathrm{C}$, the air temperature in the courtyard fluctuated between 26 and $33^{\circ} \mathrm{C}$. This was due to the small, two-level shaded courtyard, which helps cool the airflow inside the rooms and ensures ventilation throughout the building even when the weather outside is calm. The outdoor relative humidity varied from 22 to $55 \%$, but the relative humidity in different indoor spaces varied from 32 to $45 \%$, which was within the comfort zone (Fig. 16). We found that the maximum external surface temperature-that of an exposed wall in the afternoon-reached $54^{\circ} \mathrm{C}$, whereas the temperature of the wall's surface inside the house was $33^{\circ} \mathrm{C}$. This can be attributed to the time lag, occurring due to the wall's massive, $45 \mathrm{~cm}$ thickness. The temperatures in different spaces on
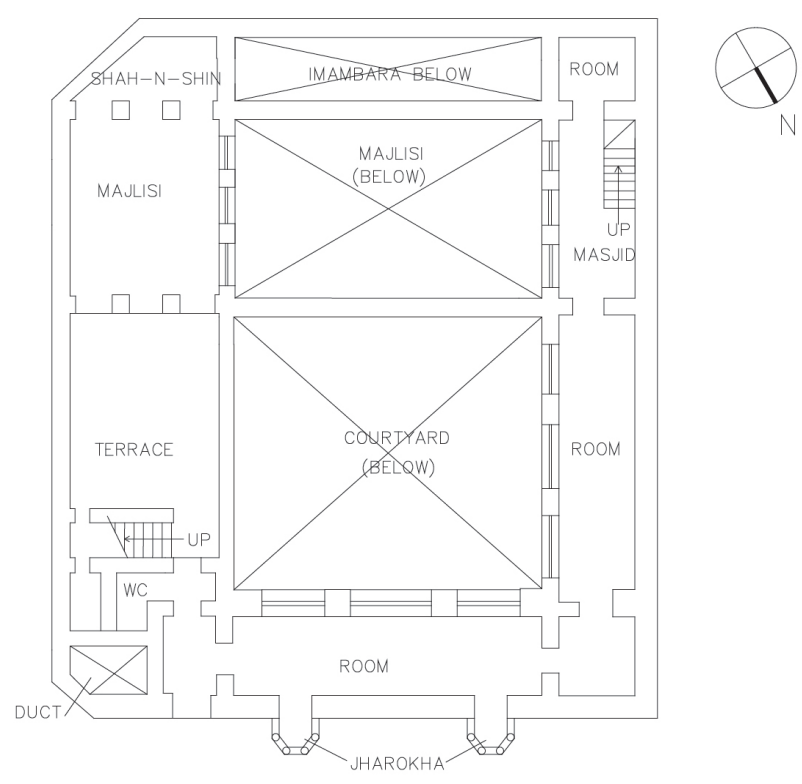

Figure 14. First-floor plan of Rizvi House (Source: the author of the paper)

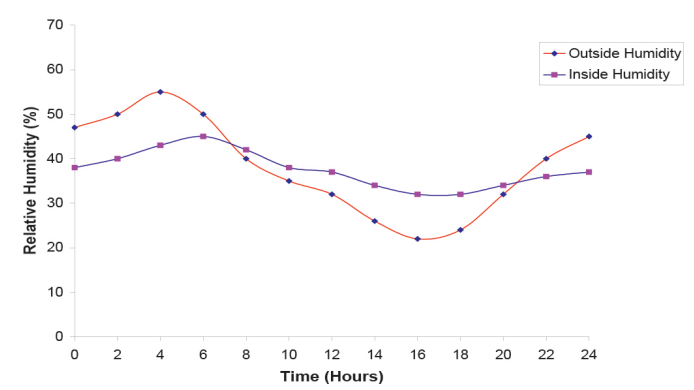

Figure 16. Relative humidity in Rizvi House in the summer (Source: the author of the paper) 


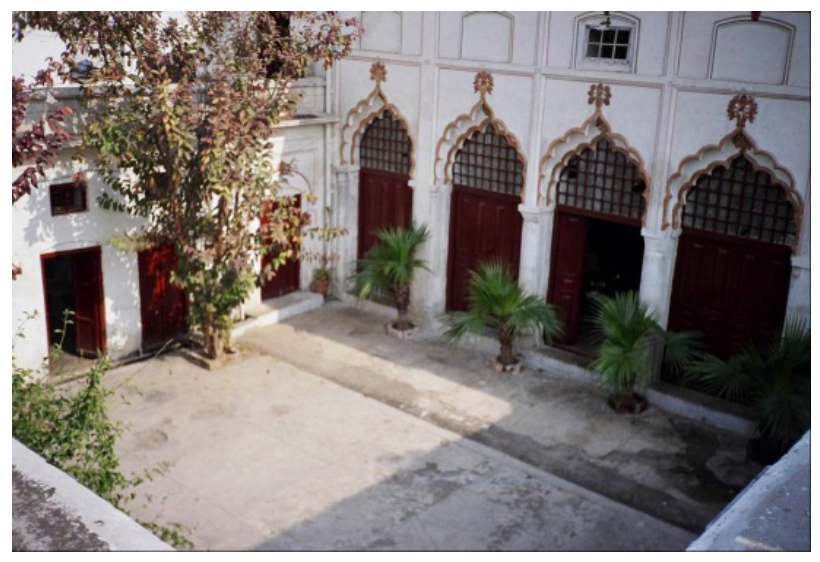

Figure 18. View of the central courtyard of Qaiser Jahan House (Source: the author of the paper)

the first floor were consistently higher by 1 to $1.5^{\circ} \mathrm{C}$. Winter

Thermal Performance of Rizvi House in the

It is clear from the graph in Figure 17 that the outdoor temperature fluctuated from 8.5 to $22^{\circ} \mathrm{C}$, but the indoor temperature in different spaces was never less than $16^{\circ} \mathrm{C}$, even though the inside of the building received very little direct solar radiation. The indoor temperature fluctuation in different rooms was in the range of $4-5^{\circ} \mathrm{C}$.

\section{Case Study 2: Qaiser Jahan House}

This is the courtyard house of the late Mrs. Qaiser Jahan Begum, which is around 125 years old. The house opens into a narrow street through an entrance lobby, which also opens directly into the courtyard (Fig. 18). The square-shaped (10.75 x 10.0 $\mathrm{m}$ ) courtyard is centrally located, enclosed by rooms

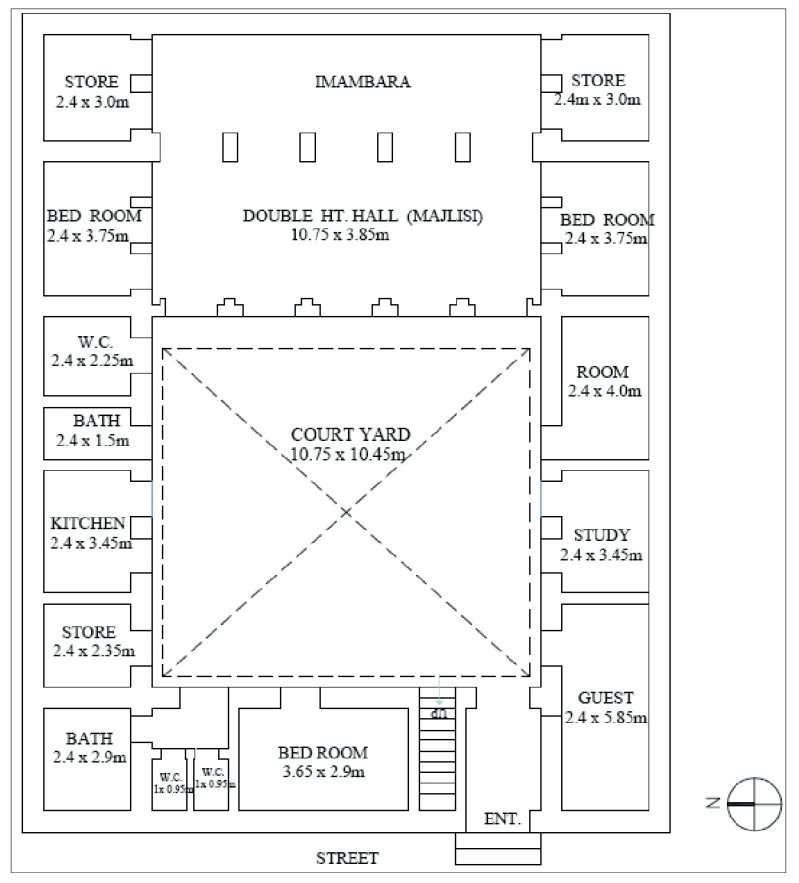

Figure 20. Ground-floor plan of Qaiser Jahan House (Source: the author of the paper)

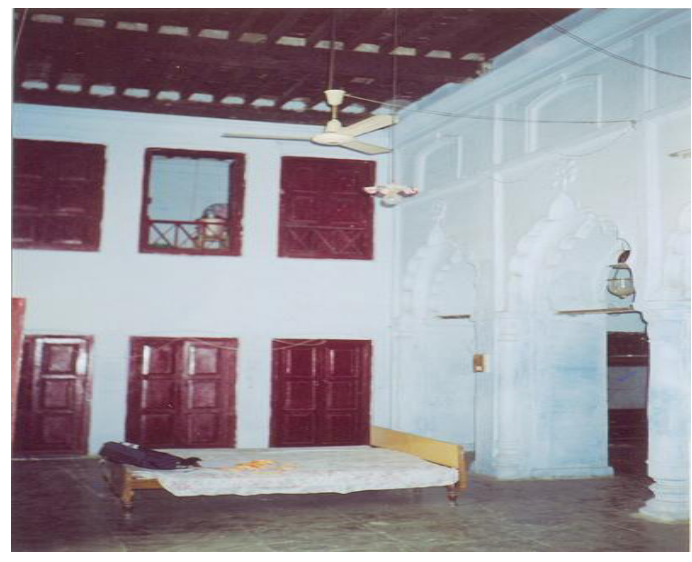

Figure 19. Two-level room with timber ceiling in Qaiser Jahan House (Source: the author of the paper)

on three sides, and has an entrance on the west side. There is a two-level hall on the eastern side of the courtyard; the other three sides are surrounded by single-level structures. The two-level hall opens into an Imambara and two bedrooms. This hall is also used as a «mourning place» during Moharram (Fig. 19). The configuration of Qaiser Jahan House is shown in Figure 20.

\section{Passive Features of Qaiser Jahan House}

The house opens into the narrow street, which is shaded by the balcony and projections of the buildings on both sides. The entrance to the house is through a lobby, which opens into the central courtyard. As the courtyard gets heated up during the day, the hotter air rises and the denser cool air, which is drawn from the shaded streets, rushes into the courtyard, ventilating the interiors of the surrounding rooms. The absence of openings on the exterior surfaces helps reduce heat. The twolevel entrance on the southwest side shades the building from the afternoon sun. The walls are 60 $\mathrm{cm}$ thick and constructed out of lakhauri bricks finished with lime surkhi plaster. The roof is $45 \mathrm{~cm}$ thick and constructed out of brick ballast, mixed with lime surkhi mortar and laid on timber planks supported by timber beams (Fig. 20). The massive walls, heavy roof, and timber ceiling offer greater

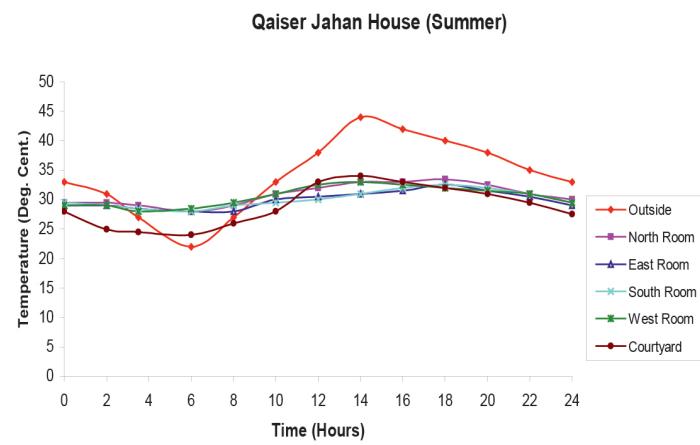

Figure 21. Summer temperature in different spaces of Qaiser Jahan House (Source: the author of the paper) 
thermal insulation and increase the thermal time lag. The ventilation apertures facilitate the stack effect and extract the warm air from the rooms. There is also vegetation in the surroundings, which provides evaporative cooling. The exterior of the building is plastered with lime mortar and whitewashed, which reflects the solar radiation to some extent.

Thermal Performance of Kaiser Jahan House in the Summer

Figure 21 shows the thermal performance of different spaces inside and outside the building on June 6 . The outdoor temperature fluctuation was in the range of $12-13^{\circ} \mathrm{C}$, whereas the indoor temperature fluctuation was around $4-5^{\circ} \mathrm{C}$. The

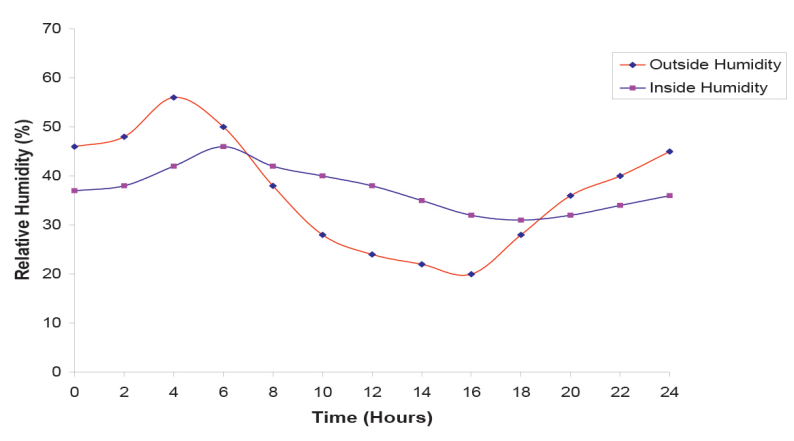

Figure 22. Relative humidity in Qaiser Jahan House in the summer (Source: the author of the paper)

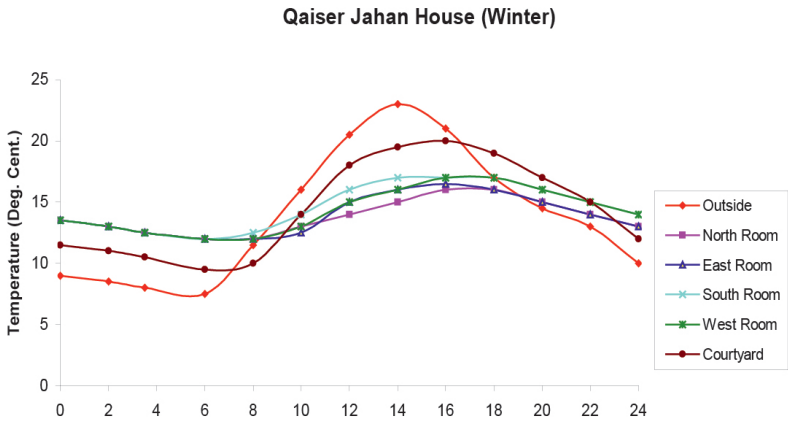

Figure 23. Winter temperature in different spaces in Qaiser Jahan House (Source: the author of the paper)

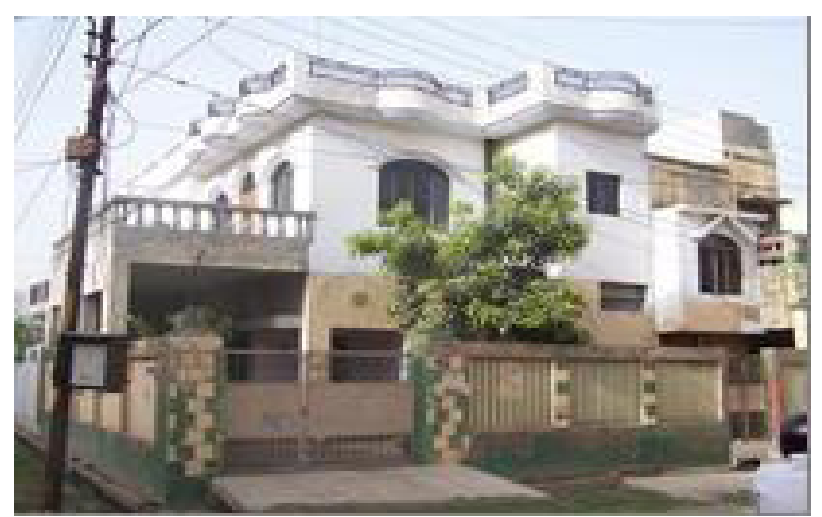

Figure 24. Front view of the contemporary LDA House (Source: the author of the paper) maximum indoor temperature was $9-10^{\circ} \mathrm{C}$ lower than the corresponding outdoor temperature. While the outdoor air temperatures changed from 22 to $44^{\circ} \mathrm{C}$, the air temperature in the courtyard fluctuated between 24 and $34^{\circ} \mathrm{C}$. The temperature in the courtyard of Qaiser Jahan House was found to be a little higher than in the courtyard of Rizvi House in the afternoon and a little lower in the early morning. This can be attributed to the bigger courtyard in Qaiser Jahan House as compared to Rizvi House. The outdoor relative humidity varied from 20 to $56 \%$, but the relative humidity in different spaces varied from 31 to $46 \%$, which was within the comfort zone (Fig. 22). The overall relative humidity, in this case, was lower than in Rizvi House, because of the bigger courtyard and more cross ventilation in the rooms. We found that the maximum external surface temperature-that of an exposed wall in the afternoon-reached $55^{\circ} \mathrm{C}$, whereas the temperature of the wall's surface inside the house was $34^{\circ} \mathrm{C}$. This can be attributed to the time lag due to the wall's massive, $60 \mathrm{~cm}$ thickness.

\section{Thermal Performance of Kaiser Jahan House in the Winter}

The temperatures measured in different rooms of Qaiser Jahan House were found to be slightly higher during the daytime and slightly lower during the night, as compared to Rizvi House. This can, once again, be attributed to the presence of a bigger courtyard in Qaiser Jahan House. As shown in Figure 23, the outdoor temperature fluctuated between 7.5 and $23^{\circ} \mathrm{C}$, but the indoor temperature of different spaces was never less than $12^{\circ} \mathrm{C}$. The indoor temperature fluctuation in different rooms was in the range of $4-5^{\circ} \mathrm{C}$.

\section{Case Study 3: LDA House}

This building is a MIG (Middle Income Group) house, which was built by the Lucknow Development

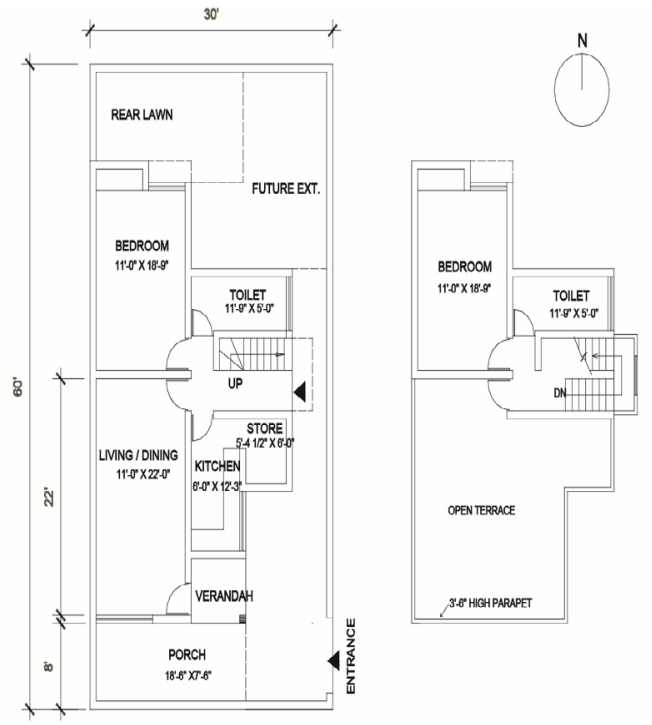

Figure 25. Ground- and first-floor plan of LDA House (Source: the author of the paper) 
Authority in Aishbagh, Lucknow, around 40 years ago (Fig. 24). It is a double-storey building with a living room, a kitchen, a bathroom, and a bedroom on the ground floor and a bedroom and a bathroom on the upper floor. The construction consists of 23-cm-thick load-bearing brick masonry walls and a $6 »$-thick roof. The rooms are $3.0 \mathrm{~m}$ tall and openings have $0.9 \times 1.2 \mathrm{~m}$ dimensions.

\section{Salient Features of LDA House}

This building is a part of semi-detached row housing and is compactly planned, with a small front and rear yard. Energy consumption was not considered as a design criterion for houses of this type. There are only a few openings, which face the front and rear yard; this obstructs free air movement and does not provide cross ventilation. The living room is located on the western side without proper shading, which causes discomfort in the summer (Fig. 25). The roof of the first floor is a $10-\mathrm{cm}$-thick R.C.C. structure, finished with small brick ballast and cement sand mortar. The roof is a major source of heat gain for the upper floor due to the absence of appropriate terracing. There is no proper sunshade over the first-floor openings on the south and west side, hence the openings do not cut the solar radiation in the afternoon and heat up the interiors due to the high transmittance of glass. Nor is there any proper projection on the terrace level on the south and west side to shade the walls on the first floor. This causes the walls to heat up, thus letting

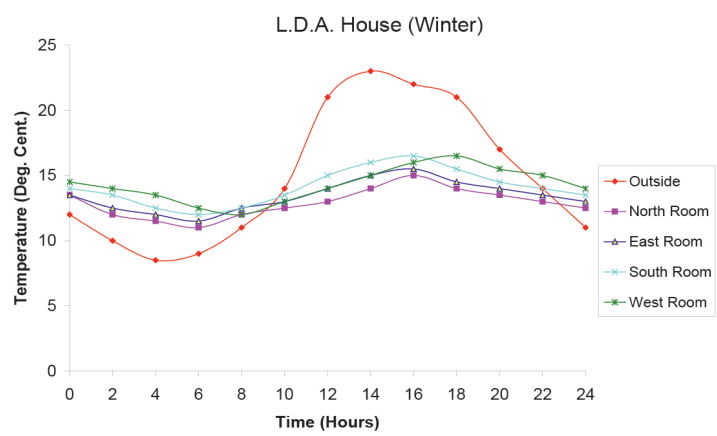

Figure 26. Summer air temperature in different spaces in LDA House (Source: the author of the paper)

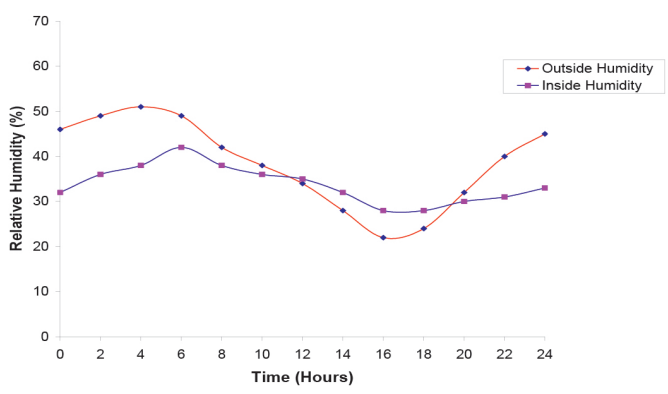

Figure 27. Relative humidity in LDA House in the summer (Source: the author of the paper) the heat into the rooms through conduction. The plastered exterior surface with whitewash reflects solar radiation to some extent.

Thermal Performance of LDA House in the Summer

The room temperature in different spaces was found to be above the slightly warm range. The outdoor temperature fluctuation was in the range of $19^{\circ} \mathrm{C}$, whereas the indoor temperature fluctuation was in the range of $7^{\circ} \mathrm{C}$. The maximum indoor temperature was $6-7^{\circ} \mathrm{C}$ lower than the corresponding outdoor temperature. In this case, we could clearly observe that the indoor temperature of this house was $4-5^{\circ} \mathrm{C}$ higher than the temperature of the traditional house during the same hours of the day (Fig. 26). This can be attributed to the thin walls, the R.C.C. structure, and the lack of proper wall shading. The outdoor relative humidity varied from 23 to $54 \%$, but the relative humidity in different indoor spaces varied from 28 to $42 \%$. The overall relative humidity with reference to thermal comfort was slightly lower than in any traditional house (Fig. 27)

\section{Thermal Performance of LDA House in the Winter}

The room temperature in different spaces was found to be below the slightly cool range. The outdoor temperature fluctuation was in the range of $15^{\circ} \mathrm{C}$, whereas the indoor temperature fluctuation was in the range of $6^{\circ} \mathrm{C}$. The maximum indoor temperature was $3^{\circ} \mathrm{C}$ lower than the corresponding outdoor temperature. In this case, we could clearly observe that the indoor temperature of this house was $4-5^{\circ} \mathrm{C}$ lower than the temperature of the traditional house during the same hours of the day (Fig. 28). This can be attributed to the thin $(23 \mathrm{~cm})$ brick masonry walls and the $10-\mathrm{cm}$ R.C.C structure without proper wall shading.

\section{Summary of the Findings}

The simultaneous monitoring of outdoor and indoor thermal conditions of two traditional houses together with those of one modern house in Lucknow has shown that the thermal capacity of the traditional houses, which have courtyards and a compact and self-shading design, has many advantages when it

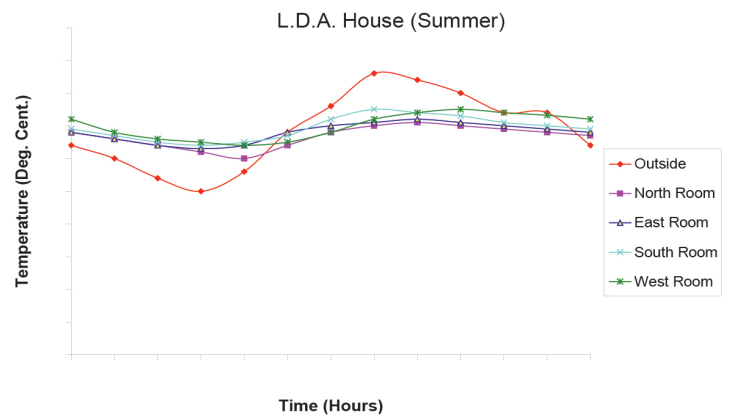

Figure 28. Winter air temperature in different spaces in LDA House (Source: the author of the paper) 
comes to limiting the daytime indoor temperature rise during the hot seasons. During the winter, the thermal capacity of the traditional houses plays a major part in maintaining near-comfort indoor conditions during the night, even when the external temperature drops as low as $7^{\circ} \mathrm{C}$. The comparative analysis of the thermal performance of the traditional and modern houses is summarized as follows:

1. The data collected shows that the indoor air temperature in the two traditional buildings is $2-3^{\circ} \mathrm{C}$ lower in the summer and $2-3^{\circ} \mathrm{C}$ higher in the winter, as compared to the indoor temperatures in LDA house.

2. The difference between the outdoor and indoor temperature in the traditional buildings is greater than in LDA house, suggesting a better comfort level in traditional buildings.

3. In the traditional houses, the indoor air temperature fluctuation was not more than $4-5^{\circ} \mathrm{C}$ while the outdoor temperature fluctuated in the range of $18-20^{\circ} \mathrm{C}$.

4. There was a thermal time lag due to the heavy thermal mass, i.e. the thick masonry walls and heavy roof construction system found in the traditional houses of Lucknow. The time lag of the whole system is around 10 hours. This allows for comfort at all times of day. The resulting temperature difference was almost $12^{\circ} \mathrm{C}$. This means that when the outdoor temperature at noon on a summer day was around $45^{\circ} \mathrm{C}$, the indoor temperature would be around $35^{\circ} \mathrm{C}$.

5 . In the summer, the average maximum indoor temperature in different rooms of the traditional house was $10-12^{\circ} \mathrm{C}$ lower and the average minimum indoor temperature was $3-4^{\circ} \mathrm{C}$ higher than the respective outdoor temperature, whereas in LDA house the average maximum indoor temperature was $5-6^{\circ} \mathrm{C}$ lower and the average minimum indoor temperature was $7-8^{\circ} \mathrm{C}$ higher than the respective outdoor temperature.

6. In the winter, there was a $4-5^{\circ} \mathrm{C}$ temperature difference between the average maximum indoor temperature in different rooms and the maximum outdoor temperature, and a $5-6^{\circ} \mathrm{C}$ temperature difference between the average minimum indoor temperature and the minimum outdoor temperature. In LDA. house, there was an $8-9^{\circ} \mathrm{C}$ difference between the average maximum indoor temperature in different rooms and the maximum outdoor temperature, and a $4-5^{\circ} \mathrm{C}$ temperature difference between the average minimum indoor temperature and the minimum outdoor temperature.

7. The peak indoor temperatures in the traditional buildings occurred at about the same time as the peak outdoor temperatures, but the time lag was around 24 hours due to the massive thickness of the walls, whereas in LDA house, the peak indoor temperature occurred around 6 p.m., while the peak outdoor temperature occurred around 2 p.m.

8 . The courtyard system in the traditional buildings ensured ventilation through the building even during the periods when the outdoor conditions were calm. The courtyard temperature was $1-2^{\circ} \mathrm{C}$ higher in the late afternoon and $2-3^{\circ} \mathrm{C}$ lower in the early morning, as compared to the indoor temperatures in the rooms. The courtyards are open to the sky or partially shaded with overhangs. This also creates shaded spaces, thus reducing heat gain. As the solar radiation enters the courtyard, the air in the courtyard becomes warmer and rises up. To replace it, the cool air from the ground level flows through the openings into the room, thus producing airflow. During the night, the process is reversed.

9. The areas of the building directly exposed to the sun were $2-3^{\circ} \mathrm{C}$ warmer in the traditional buildings due to the thick, massive walls, whereas in LDA house, they were at times $7-9^{\circ} \mathrm{C}$ warmer than the corresponding ambient air temperature.

10. The openings in the traditional houses, such as windows, vents, and the skylight, provided cross ventilation, by creating a stack effect. The ventilation apertures, such as jharokhas or jaalis, induce forced ventilation into the interiors of the buildings. The air movement occurs because of the presence of the courtyard and the difference in indoor and outdoor temperature, which creates air circulation. The contemporary house has poor air circulation, as there is no avenue for cross ventilation.

11. Traditional buildings have various features that help lower the daytime temperature: structural elements like shading devices; buffer spaces like courts, verandas, etc.; wind catcher screens; recessed openings; water bodies; and vegetation. There are very few, or hardly any such features in modern-day houses.

\section{Conclusion}

It is clear from the study that appropriate use of materials, spatial organization, construction techniques, and passive design features could bring about the much-desired comfortable environment inside the house. Natural cooling can be achieved by the proper orientation of the building, an appropriate layout, a good landscape design, proper shading devices, and a properly designed roof, overhangs, external surface finish, and vertical shadings, oriented in an optimal way in relation to the sun and wind. We can infer from the analysis of our experiments that the traditional building form, structure, and materials were originally selected to suit the climatic conditions and ensure optimal comfort and shelter from climatic factors invading indoors, without any mechanical means, i.e. heaters, fans, coolers, air conditioners, etc. The traditional architecture of Lucknow features well-shaded buildings with heavy facades and limited openings on the external elevation. The basic form of the traditional building employs a combination of mass, shade, and ventilation, which lets the building breathe in harmony with nature and ensures the best range of comfort conditions for the occupants 
inside. The principles of good thermal design used in traditional buildings are still valid today, and it would still be possible for modern designers and architects to incorporate these design principles into buildings that are suitable for modern-day living, in order to conserve energy and provide better thermal comfort. Perhaps the solution lies in rediscovering the features and techniques used in traditional buildings and recreating them in the contemporary architectural form.

The region-specific built forms are a result of centuries of experimentations, shaped by social, cultural, religious, and technological influences. They would be continuously refined by subsequent generations, albeit at a very slow pace and through trial and error, depending on societal characteristics, technology, and materials. As a result, these built forms served the purpose very well, being rooted in their locale; they satisfied the functional, climatic, and aesthetic aspirations of their users. It is known that the value of traditional regional architecture is not limited to it being cultural heritage, which is reason enough for its study. Such architecture also has tremendous potential for influencing the current architectural trends in the respective region (Krishna and Rewatkar, 2006). The real challenge is to achieve maximum thermal comfort at a minimum energy cost, through adjusting various energy conservation measures and techniques at the building design and construction stage. It is an architect's responsibility to be mindful of the climate and aim for energy efficiency and human comfort while designing modern-day buildings. There is a need for establishing a planning and design methodology, based on the philosophy of translating the spirit of the old into an idiom of the new design, instead of mere superficial recreation. An architect needs to understand how to blend lessons from the traditional heritage together with modern technology in building design. Hence it is essential to take the wisdom of the past and evolve the built form, creating the more humanized, more climate-responsive, and more environmentally friendly buildings of tomorrow. 


\section{References}

Asquith, L. and Vellinga, M. (2006). Vernacular architecture in the $21^{1 \text { ts }}$ century: theory, education and practice. London and New York: Taylor and Francis, 312 p.

Bay, J. (2010). Towards a Fourth Ecology: social and environmental sustainability with architecture and urban design. Journal of Green Building, 5 (4), pp. 176-197.

Central Building Research Institute (CBRI) (1969). Climatological and solar data for India: To Design Buildings for Thermal Comfort. $2^{\text {nd }}$ edition, Meerut: Sarita Prakashan, $166 \mathrm{p}$.

Coch, H. (1998). Chapter 4-Bioclimatism in vernacular architecture. Renewable and Sustainable Energy Reviews, 2 (1-2), pp. 67-87. DOI: 10.1016/s1364-0321(98)00012-4.

Kamal, M. A. (2007). Energy responsiveness in traditional residential buildings of Lucknow. PhD Thesis in Architecture and Planning. Roorkee: Indian Institute of Technology.

Krishan, A., Baker, N., Yannas, S. and Szokolay, S. V. (2001). Climate responsive architecture: a design handbook for energy efficient buildings. New Delhi: Tata Mcgraw-Hill Publishing Co. Ltd., 409 p.

Krishna, A. and Rewatkar, K. (2006). The relevance of heritage architecture in today's context. Journal of Indian Institute of Architects, 71 (8).

Rapoport, A. (1969). House form and culture. Englewood Cliffs: Prentice Hall Publications, 150 p.

Robert, A. and Kummert, M. (2012). Designing net-zero energy buildings for the future climate, not for the past. Building and Environment, Vol. 55, pp. 150-158. DOI: 10.1016/j.buildenv.2011.12.014.

Saleh, M. A. E. (1999). Al-Alkhalaf: the evolution of the urban built-form of a traditional settlement in Southwestern Saudi Arabia. Building and Environment, 34 (6), pp. 649-669. DOI: 10.1016/S0360-1323(98)00047-X.

Sangkertadi, Tungka, A. and Syafriny, R. (2008). Thermal comfort comparison of traditional architecture and modern style housing in North Sulawesi - Indonesia. In: Proceedings of the $9^{\text {th }}$ SENVAR International Seminar \& $2^{\text {nd }}$ ISESEE, December 1-3, 2008, Kuala Lumpur, Malaysia.

Sayigh, A. and Marafia, H. (1998). Chapter 1-Thermal comfort and the development of bioclimatic concept in building design. Renewable and Sustainable Energy Reviews, 2 (1-2), pp. 3-24. DOI: 10.1016/s1364-0321(98)00009-4.

Sinha, A. and Kant, R. (2000). Urban evolution and transformations: study of medieval and colonial streets in Lucknow. Architecture+Design (A+D), 17 (5), pp. 66-71.

Tandan, B. (2001). The architecture of Lucknow and its dependencies, 1792-1856: A descriptive inventory and an analysis of Nawabi types. New Delhi: Vikas Publishing House Pvt. Ltd., 321 p.

Vissilia, A.-M. (2009). Evaluation of a sustainable Greek vernacular settlement and its landscape: architectural typology and building physics. Building and Environment, 44 (6), pp. 1095-1106. DOI: 10.1016/j.buildenv.2008.05.026. 